\title{
How to achieve sustained and complete protein release
}

\section{from PLGA-based microparticles?}

A.Giteau $^{\mathrm{a}}$, M.C. Venier-Julienne ${ }^{\mathrm{a} *}$, A. Aubert-Pouëssel ${ }^{\mathrm{b}}$, J.P. Benoit $^{\mathrm{a}}$

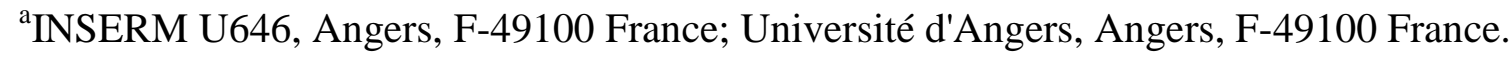

bUMR CNRS, ENSCM, UM1 5618, Montpellier, F-34296 France.

\section{Keywords}

Sustained release; protein; microspheres; poly(lactic-co-glycolic acid) (PLGA); in vitro release; release mechanism.

* Corresponding author. Tel.: +33 241 735855; Fax: +33 241 735853; E-mail address:

venier@univ-angers.fr 


\section{Abstract}

One of the most challenging tasks in the delivery of therapeutic proteins from PLGAbased microparticles is the sustained and complete release of the protein in its native form. The mechanisms responsible for incomplete protein release from these devices are numerous and complex; the beneficial effect of different formulations has often been evaluated in vitro. Strategies employed for overcoming protein destabilization during the release step are reviewed in this paper. Proteins have been protected in the deleterious environment by adding stabilizers to the formulation, or by modifying the protein or the polymer. Alternatively, some strategies have aimed at avoiding the formation of the destabilizing environment. As experimental conditions may influence the results from in vitro release studies, we initially report precautions to avoid adverse effects. 


\section{Table of contents}

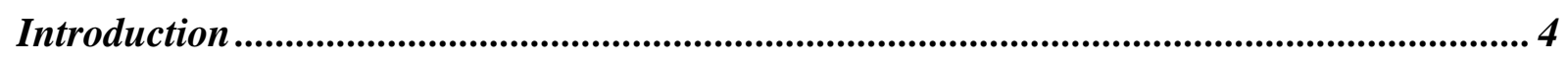

1 Influence of the experimental conditions on the release profile .....................................5

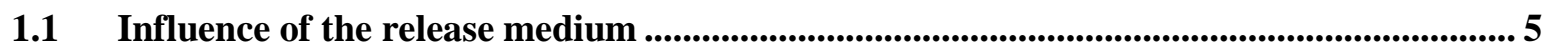

1.2 Influence of the sampling method.................................................................................................. 7

2 Trends toward a sustained and complete release .................................................... 10

2.1 Stabilizing proteins in the deleterious environment ................................................................. 12

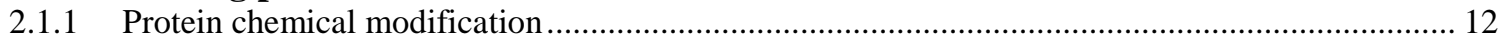

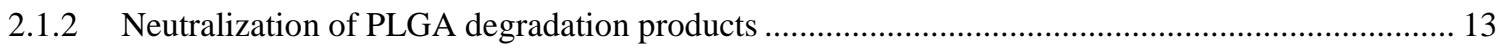

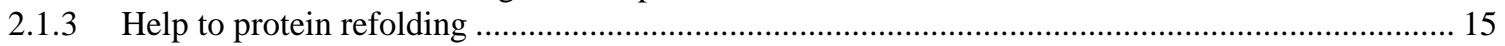

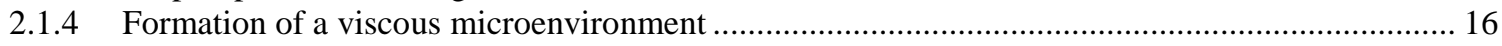

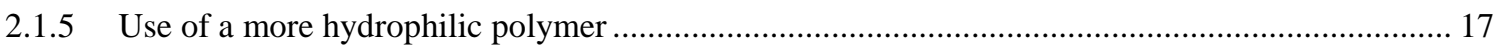

2.2 Preventing the formation of the deleterious environment................................................... 20

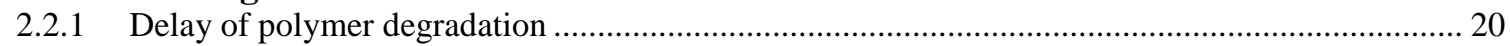

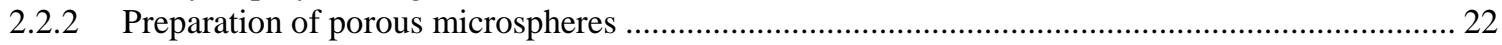

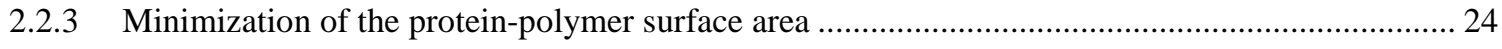

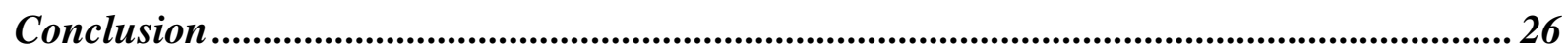

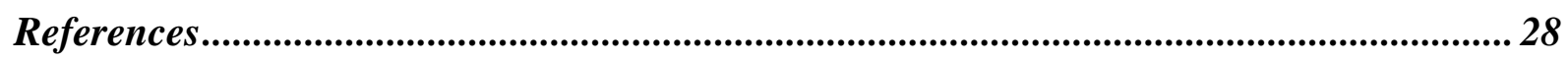




\section{Introduction}

Developments in biotechnology have seen the growing use of proteins and peptides as therapeutic agents. However, expectations concerning the delivery of therapeutic proteins have been limited by their fragile structure and the frequent administrations required (Yang et al., 1997; Lam et al., 2000; Sinha et al., 2003). To protect them from proteolysis, to allow for their sustained delivery and to enhance their therapeutic efficacy, their encapsulation in injectable, biodegradable microparticles has been explored (Pean et al., 1999; Rosa et al., 2000; Aubert-Pouessel et al., 2004).

Polymers derived from D,L lactic and glycolic acids, poly(lactide-co-glycolide) (PLGA), are biocompatible and biodegradable (Visscher et al., 1985; Fournier et al., 2003), they have been widely employed with this aim in mind. Drug release from these systems is due to drug diffusion through water-filled networks of pores and channels coupled with the bulk erosion of the microspheres by hydrolysis of the polymer's ester bond linkages. This classical model, which has been observed for small hydrophobic molecules, is not always relevant for proteins: a high initial burst followed by a very slow release or no release at all has been observed in many cases. The burst effect is generally attributed to the rapid diffusion of the drug located at the surface of the microparticles. Many studies (Pean et al., 1999; Lam et al., 2001; Perez et al., 2003; Wang et al., 2004; Kim et al., 2005) and reviews (Schwendeman et al., 1996; Wang et al., 1999; Burke et al., 2000; van de Weert et al., 2000; Perez et al., 2002; Bilati et al., 2005; Tamber et al., 2005; Wang et al., 2005) have addressed protein stability issues occurring during the formulation process. However, few results have shown a suitable protein release profile.

Releasing a protein according to a zero-order profile and without denaturation in the course of the polymer degradation process is very challenging. When protein is released over time, other protein instability problems may occur within PLGA microspheres. This results in 
varying degrees of incomplete release subsequent to the initial burst, even after the PLGA copolymer has been substantially degraded. This feature certainly remains one of the most important hurdles for successful protein delivery from biodegradable microspheres.

The methods proposed to prevent incomplete release are often unsuccessful for many proteins. The importance of the conditions in which the in vitro protein release profile is established is often underestimated and confusing release results are common. By considering the influence of these parameters, the development of protein stabilizing strategies becomes possible. This article describes trends towards a better protein release profile with examples of successful and failed sustained release of model and therapeutic proteins. The paper focuses on studies performed with microparticles of biodegradable polymers from lactic and glycolic acids. Aspects concerning protein stability issues during the encapsulation step are not addressed; nevertheless, they should be solved before studying the release as they might drastically influence the final protein release pattern.

\section{Influence of the experimental conditions on the release}

\section{profile}

\subsection{Influence of the release medium}

A variety of proteins have been encapsulated in polymeric carriers (see Bilati et al., 2005 for a review). The various entrapped proteins differ in terms of their physico-chemical properties (i.e. molecular weight, solubility, distribution coefficient, number of free thiol groups and/or disulfide bonds) and their therapeutic functions (Sandor et al., 2001). These differences imply different reactions to stress factors (Sah et al., 1999), different interactions with PLGA degradation products (Blanco et al., 1998) and especially different stability issues in the incubation medium (Wang et al., 2005). 
Most of the authors used Phosphate Buffer Saline (PBS) pH 7.4 at $37^{\circ} \mathrm{C}$ for the in vitro studies, because it is the buffer with the nearest physiological conditions. As only a few proteins such as tetanus toxoid (Jung et al., 2002) are stable in these conditions, some authors performed protein stability studies to assess the in vitro release study in an optimal release medium (e.g., acetate, citrate or TRIS-HCl buffers) (Table 1). For instance, lysozyme, which was found to aggregate in phosphate buffer resulting in incomplete release, was stabilized in glycine buffer and exhibited a complete release (Figure 1) (Jiang et al., 2002).

The $\mathrm{pH}$ has a key effect on release by acting both on the polymer degradation rate and on protein stability. Firstly, acidic and alkaline media are known to accelerate polymer degradation (Makino et al., 1986). Secondly, the $\mathrm{pH}$ of a protein solution has a great influence on protein conformation. Thus, acidic $\mathrm{pH}$ may either aggregate one protein or on the contrary may stabilize another one. Lu et al. (Lu et al., 2001) studied Transforming Growth Factorbeta1 (TGF- $\beta 1$ ) release kinetics in $\mathrm{pH} 3,5$ or 7.4 buffers. They observed that the release rate decreased with the $\mathrm{pH}$, although microparticle degradation increased. They attributed this slow release to protein aggregation in the polymer matrix. In contrast, a faster and complete release of Insulin-like Growth Factor-I (IGF-1) (Lam et al., 2000) and lysozyme (Jiang et al., 2002) was observed at acidic $\mathrm{pH}$ levels ( $\mathrm{pH} 5.4$ and $\mathrm{pH} 2.5$, respectively), where these proteins are not prone to aggregation.

The increase in the ionic strength of the release medium often induces a decrease of the release rates. Authors have suggested that the increased ionic strength may reduce the swelling of the polymer matrix by reducing the diffusion of the protein from the microspheres (Hora et al., 1990; Bodmer et al., 1992). Moreover, the increase of ionic strength can affect protein stability leading to aggregation. Yang et al. (Yang et al., 1997) observed that interferon-gamma (IFN- $\gamma$ ) in solution in an iso-osmotic saline medium underwent aggregation, whereas in a buffer with low osmolarity (succinate buffer $5 \mathrm{mM}$ ), the protein 
remained stable. On the contrary, greater lysozyme amounts were released from PLGA microspheres during the first 24-day incubation period by increasing the ionic strength of the medium (by the addition of $\mathrm{NaCl}$ ). The ionic interactions between the lysozyme positive charge and carboxylic acid end-groups in PLGA were supposed to be disrupted in this release period. It is worth noticing that in the latter stages other mechanisms occurred (i.e. noncovalent aggregation and surface adsorption) leading to incomplete release (Park et al., 1998).

Therefore, in order to choose the most suitable release medium, different strategies have been carried out by different researchers. They prioritized the release of an active protein or they prioritized a simulation of the in vivo conditions via a physiological medium (PBS $\mathrm{pH}$ 7.4). In the first case, the use of a stabilizing buffer allowed researchers to better understand the causes of the denaturation of the released protein and hence to improve the formulation. Moreover, despite the use of a 'non' physiological buffer (such as acetate $\mathrm{pH} 5$ ), the in vitro release allowed good in vitro-in vivo correlations (Figure 1) (Jiang et al., 2002; Jiang et al., 2003). In the second case, it was supposed that a physiological buffer could elicit better information on the in vivo release profile of the protein. Nevertheless, when no preliminary stability studies in physiological conditions were performed and when the protein was released in a denatured state in these conditions, it appeared difficult to explain the cause of protein destabilization during release.

\subsection{Influence of the sampling method}

The in vitro release study of stable drugs from conventional formulations is common and easy. But for fragile drugs like peptides and proteins encapsulated in particulate systems, many issues are encountered. They are listed in Figure $\mathbf{2}$ as well as the various ways to avoid these artefacts during the in vitro release study from protein-loaded devices. As well as being reproducible, discriminating, and able to approach physiological conditions and to respect 
sink conditions, the technique must also prevent protein degradation prior to analysis and be able to follow the release of low amounts of protein over a sustained period with limited artefacts.

Various systems exist to characterize in vitro release kinetics of protein-loaded delivery systems (see D'Souza et al., 2006 for a review). They can be classified as: separation techniques; membrane diffusion techniques; and continuous flow techniques. Before comparing different release profiles, it is necessary to consider the method used, as some artefacts may be created.

The separation method is the most frequently used technique for protein particulate systems. It is very easy to perform as the microparticles are separated from the proteincontaining release medium at different intervals by centrifugation. Nevertheless, this method may influence the release profile. First of all, the mechanical force applied at each sample centrifugation is suspected of influencing protein release. Indeed, by packing the particles at the bottom of the tube, it may affect their physical characteristics, especially their degradation. This accelerated degradation may favour both protein alteration (acidic environment) and protein release (polymer erosion). By reducing the centrifugation speed, some researchers have been able to limit this effect (Yang et al., 1997). Moreover, low-speed centrifugation created a better correlation between in vitro and in vivo profiles (Lam et al., 2000). The choice of the release medium volume is also of great importance. Hence, Kim et al. (Kim et al., 2001) showed that by increasing this volume (from 1 to $10 \mathrm{ml}$ for $20 \mathrm{mg}$ of microparticles), the amount of released recombinant human Growth Hormone (rhGH) entrapped in PLGA microspheres by a s/o/w encapsulation procedure was increased. They hypothesized that the release rate was dependent on a thermodynamic equilibrium between reversibly-dissociable rhGH aggregates and rhGH monomers. In another work, the correlation of an increased release rate of rhGH with an increased release volume was explained by a 
better buffer capacity over the release of acidic polymer degradation products (Kim et al., 2004). In conclusion, this separation method is attractive because it requires very basic materials, it is easy to develop, and results are reproducible. However, the speed of centrifugation and the buffer volume should be adjusted for a better in vitro-in vivo correlation.

The membrane diffusion technique consists of entrapping the protein-loaded microparticles in a dialysis bag. It presents the advantage of maintaining a constant $\mathrm{pH}$ level during the release study because the acidic degradation products can diffuse through the membrane (Park et al., 1995). However, it is important to remember that, with this method, the volume of the acceptor compartment is high; it is therefore inappropriate for the study of protein release because of protein adsorption to the dialysis membrane and because of low protein detection due to protein dilution.

Finally, the continuous flow method has sometimes been used. It employs cells to entrap samples; they are fed continuously with a releasing medium from a pressurized reservoir. There is no effect related to the acidification of the medium because of the continuous replenishment of the buffer, nor is there an effect related to the use of centrifugation forces. This system mimics the in vivo conditions in which particles are exposed to a flowing biological fluid. However, it is not often used, maybe because of the complexity of the materials. A good in vitro-in vivo correlation was possible with this system as demonstrated for microspheres loaded with rhGH and suspended in HEPES (pH 7.4) (Cleland et al., 1997). The authors observed in vitro release profiles similar to the in vivo conditions (a triphasic profile characterized by a small burst and then by a complete release). A modified continuous flow system was developed by Aubert-Pouëssel et al. (Aubert-Pouessel et al., 2002). The methodology was intended to prevent protein degradation (by collecting the protein fractions 
at $4^{\circ} \mathrm{C}$ ) and to avoid protein adsorption prior to analysis (by using an adsorption resistant material in $\left.\mathrm{PEEK}^{\circledR}\right)$.

To conclude, when evaluating the release kinetics of a protein from PLGA microspheres, it is essential to keep in mind that low release levels of protein may be due not only to protein denaturation during the formulation process or polymer degradation, but also due to the experimental conditions (by medium acidification, destabilizing release medium etc.). For a more appropriate interpretation of the results, the amount of 'total' released protein (determined by bicinchoninic acid assay (Al-Azzam et al., 2002), High Performance Liquid Chromatography (HPLC) (Jiang et al., 2003), radioactivity count (Aubert-Pouessel et al., 2002), Enzyme Linked Immuno Sorbent Assay, ELISA) (Aubert-Pouessel et al., 2004)...) and the amount of biologically-active released protein (Aubert-Pouessel et al., 2002) may be simultaneously estimated. Hence, the 'active' and 'total' release profiles may be compared and the integrity of the released protein may be assessed. In the same way, the three-dimensional conformation may be analyzed by Size Exclusion Chromatography-HPLC (SEC-HPLC) (Wang et al., 2004), Sodium Dodecyl Sulfate-Poly Acrylamide Gel Electrophoresis (SDSPAGE) (Woo et al., 2001), Circular Dichroism (CD) (Kwon et al., 2004) and Fourier Transform Infrared Spectroscopy (FTIR) (Carrasquillo et al., 2001).

\section{Trends toward a sustained and complete release}

Protein release from PLGA devices is governed by diffusion through aqueous pores in the initial phase, erosion of the polymeric matrix at later stages, and additional factors responsible for the incomplete release such as the affinity of the protein for the polymer and inherent protein instability problems occurring during polymer erosion. The mechanism of incomplete protein release is illustrated in Figure 3. 
During the initial phase of microsphere hydration, the protein is prone to moistureinduced aggregation (Costantino et al., 1994). Later, ionic interaction may occur between proteins positively charged at neutral $\mathrm{pH}$ (e.g. lysozyme) and carboxylic acid end-groups in uncapped PLGA (Blanco et al., 1998; Park et al., 1998). Hence, when $\mathrm{NaCl}$ was added into the incubation medium during the in vitro release study of lysozyme from PLGA microspheres, increased lysozyme release was observed (Park et al., 1998). This effect was only significant in the early stage of incubation (first 15 days) (Park et al., 1998).

Later, when the polymer starts to degrade, non-specific adsorption on the degrading PLGA surface, covalent/non-covalent aggregation, and denaturation may occur (Crotts et al., 1998). This was supported by comparing the amount of released protein with or without $5 \mathrm{M}$ Guanidine hydrochloride $(\mathrm{GuHCl})$ or $5 \mathrm{mM}$ sodium dodecyl sulphate (SDS) in the incubation medium (Park et al., 1998; Kim et al., 1999). GuHCl dissociates non-covalently aggregated proteins and SDS minimizes non-specific adsorption in addition to the dissociation of noncovalent aggregates (Crotts et al., 1998).

The presence of non-covalent aggregates was confirmed by performing an SDS-PAGE under non-reducing conditions on the encapsulated protein remaining within microspheres, at different release days. Covalent aggregation via thiol-disulphide exchange-reaction due to acidification inside the microspheres was also demonstrated using an SDS-PAGE under reducing conditions (Park et al., 1998; Kim et al., 2004). Additionally, chemical degradation reactions such as acylation (Lucke et al., 2002) and deamidation (Ibrahim et al., 2005), not detected by the SDS-PAGE results, may happen during the incubation period and they should also be considered.

The factors affecting protein release rates are numerous and complex. Moreover, these phenomena may coexist so that formulation strategies that are efficient in counteracting all these destabilizing mechanisms are not frequent. These approaches may be classified in two 
sections presented in Table 2. Firstly, some advances are aimed at stabilizing the protein during the release step. Other processes tend to avoid protein destabilization mechanisms by achieving protein release prior to damage due to polymer erosion.

\subsection{Stabilizing proteins in the deleterious environment}

The use of additives during the encapsulation process has been extensively studied and certainly represents the most widely-employed strategy to minimize protein degradation associated with the direct environment of degrading PLGA. However, adequate in vitro release profiles were rarely generated from these formulations, even when the stabilization of the encapsulated protein by preferential hydration was successful. In general, these additives predominantly influenced the initial drug release phase but the discontinuous in vitro release behaviour was not significantly modified; they could not eliminate the non-release of aggregated proteins, possibly because of their rapid diffusion from the microparticles. It was supposed that when water entered the microspheres, the protein and the hydrophilic additives were released in a burst manner. Thus, it was shown that the stabilizing effect of saccharides varied depending upon their molecular weight and structure, with a better stabilization for higher molecular-weight substances (dextran and heparin) which were released slowly from the microspheres (Sanchez et al., 1999). As a result of this, more specific strategies were engineered to ensure protein stabilization during the release step (Figure 4).

\subsubsection{Protein chemical modification}

The conjugation of proteins with polyethylene glycol (PEG) is known to enhance protein stability in solution as revealed in relevant clinical results (Harris et al., 1998). 
Besides, pegylated proteins are good at reducing protein adsorption onto surfaces. Lysozyme adsorption onto the surface of blank PLGA microspheres was thereby reduced when it was conjugated with methoxyPEG (mPEG, MW 5000) (Diwan et al., 2001). During PLGA microsphere degradation, as protein release is limited by protein adsorption onto the enlarged surface polymer area (Crotts et al., 1997), protein chemical modification enhanced protein release rates as demonstrated for lysozyme (Diwan et al., 2001), interferon- $\alpha$ (Diwan et al., 2003) and $\alpha$-chymotrypsin (Castellanos et al., 2005). However, the preferential location of surface-active pegylated protein on the surface of microspheres also increased burst release; an initial burst superior to $50 \%$ within the first day of incubation was induced by the covalent modification of $\alpha$-chymotrypsin with PEG (Castellanos et al., 2005).

In their aqueous-solution state, proteins can become covalently aggregated via thioldisulphide exchange reactions; this phenomenon may generate an incomplete release. By blocking the free thiol group of BSA by a carboxy-methyl group, with excellent aqueous stability, no aggregation in microspheres after 28 days of incubation occurred, and protein release over 56 days was recorded (Crotts et al., 1997).

Such chemical modifications are interesting to increase the protein release rate from PLGA microspheres, but it is essential to control the formation of a new chemical entity by dealing with its probable modified physico-chemical properties and its changed activity relative to the native protein.

\subsubsection{Neutralization of PLGA degradation products}

A particular feature of PLGA degradation is the formation of acidic degradation products. The increasing number of carboxylic end-groups causes a concomitant drop of the $\mathrm{pH}$ level in the degrading PLGA matrix. The decrease of the $\mathrm{pH}$ value results in non-covalent aggregation, thereby in a non-releasable protein mass (Crotts et al., 1998; van de Weert et al., 
2000). To circumvent acid-induced protein aggregation, basic salts were co-encapsulated within PLGA microspheres to neutralize acidic PLGA degradation products. The incorporation of $\mathrm{Mg}(\mathrm{OH})_{2}$ strongly stabilized BSA, recombinant human basic fibroblast growth factor (bFGF), and bone morphogenic protein-2, and facilitated continuous protein release from cylindrical PLGA implants (Zhu et al., 2000; Zhu et al., 2000). The choice of the basic salt is of great importance: Its strength and its ability to diffuse in the network of pores strongly impacts on the release profile. Indeed the use of a strong base (e.g. $\left.\mathrm{Ca}(\mathrm{OH})_{2}\right)$ resulted in a short release duration, while a weak base (e.g. $\mathrm{ZnCO}_{3}$ ) could not eliminate aggregation, suggesting the maintenance of a low $\mathrm{pH}$ level. Besides, although $\mathrm{Mg}(\mathrm{OH})_{2}$ strongly inhibited the formation of BSA aggregates in cylindrical implants, the co-encapsulation of $\operatorname{Mg}(\mathrm{OH})_{2}$ in microspheres has been moderately successful in inhibiting BSA aggregation (Zhu et al., 2000) because its distribution was not homogeneous in the microspheres. To facilitate base diffusion through the network of aqueous pores, a more water-soluble salt should be employed such as $\mathrm{MgCO}_{3}$ which has an alkalinity level equivalent to that of $\mathrm{Mg}(\mathrm{OH})_{2}$ but which is about 10fold more water soluble. In fact, it stabilized BSA better than $\mathrm{Mg}(\mathrm{OH})_{2}$ in microspheres (Zhu et al., 2000). Other less familiar basic salts have been incorporated in PLGA formulations; they have improved the in vitro release profile (sodium bicarbonate (Shao et al., 1999)) or had negligible effects (calcium carbonate, calcium orthophosphate and sodium acetate (Johansen et al., 1998)). In most cases, this buffering approach increased the stability of the released protein in vitro. Nevertheless, protein release profiles from PLGA microspheres were not fully controlled. Modulation of both stability and release kinetics by adding other excipients or by incorporating a salt in a different way seems necessary. 


\subsubsection{Help to protein refolding}

Proteins entrapped in lyophilized microspheres are very stable because they are in the solid-state but when their water content increases, their flexibility is enhanced and they are more sensitive to deleterious conditions. Moreover, as proteins become slowly hydrated (i.e. slower than direct reconstitution), high internal protein concentration is generated which favours protein aggregation (Costantino et al., 1994; Costantino et al., 1994). Strategies intending to circumvent moisture-induced protein aggregation, either by enhancing protein diffusion or by stabilizing the protein by increased water activity, are emerging. Hence, urea, a protein unfolding agent was used to create an unfolded lysozyme form which diffuses more easily through porous channels within the microspheres than do aggregated or folded ones (Nam et al., 2000). Interestingly, a correct conformation after refolding was maintained in the release medium. Besides, to stabilize the protein during the slow protein transition from solid to liquid state, proteins were coupled with additives The interest in the engineering of proteinzinc complexes, insoluble and reversible, has been reported (Johnson et al., 1997) and was efficient in reducing NGF aggregation during its release from PLGA microspheres (Lam et al., 2001). Although metal-induced precipitation of protein therapeutics requires a protein with a zinc binding site and specific conditions to obtain a reversible complex (zinc:rhGH > 2:1; zinc:rhNGF > 18:1), this approach is very attractive. Ammonium sulphate was also used by Alkermes to minimize moisture-induced protein aggregation during slow microsphere hydration (Zale et al., 1997). Using the ProLease ${ }^{\circledR}$ spray-freeze process, a microsphere formulation composed of a solid-state protein was developed. EPO was precipitated with ammonium sulphate within the microspheres and it was supposed that no high local protein concentration could appear thanks to the mechanism of salting-out. The sustained-release of non-aggregated EPO could be achieved with this strategy. Finally, protein particles surrounded by a amphiphilic polymer phase have been prepared by lyophilization (Morita et 
al., 2000) and then encapsulated in PLGA microspheres (Morita et al., 2000; Morita et al., 2001; Morita et al., 2001; Al-Azzam et al., 2002; Lagarce et al., 2006). The sustained release of various proteins such as bovine superoxide dismutase (Morita et al., 2000), BSA (Morita et al., 2001; Al-Azzam et al., 2002) and interleukin-18 (Lagarce et al., 2006) was achieved (Figure 5). The continuous PEG phase may have protected them from aggregation within the hydrating microspheres. However, the remaining amount of PEG in the freeze-dried protein product led to an important initial burst, and so, an adaptation of the process was necessary (adjustment of the polymer composition).

\subsubsection{Formation of a viscous microenvironment}

During the incubation stage, moisture-induced aggregation and interaction with the polymer can limit protein release. Isolating the protein from its microenvironment appears to be most obvious method of protection to stabilize entrapped protein drugs and to improve release profiles. Viscosity around the protein has been successfully enhanced with this aim in mind. Initial studies were based on the design of heterogeneously structured microspheres. Firstly, hydrophilic inner microparticles were made of gelatin (Li et al., 1997), agarose (Wang et al., 1998), PVA (Wang et al., 1999) and starch (Woo et al., 2001; Capan et al., 2003; Jiang et al., 2003) and they were then combined with the PLGA matrix. Although quite timeconsuming, these composite microspheres loaded with BSA, horseradish peroxidase, and rhGH, showed more favourable and sometimes complete in vitro release than conventional PLGA microspheres (Woo et al., 2001) (Wang et al., 1998; Wang et al., 1999). Interestingly, composite PLGA-starch microspheres loaded with insulin exhibited a sustained and complete release without burst in $10 \mathrm{mM}$ glycine buffer $\mathrm{pH} 2.8$ with a good vitro-vivo correlation (Jiang et al., 2003). Later, similar but simpler effective approaches were reported. The viscous agent 
was added directly to the formulation either in the aqueous or organic phase. The thermogelling poloxamer 407 added in the inner aqueous phase protected urease during encapsulation by a w/o/w method and increased its in vitro release rate (Sturesson et al., 2000). Other viscous products such as starch and hyaluronate have been used to solve issues relative to protein stability and delivery (Lee et al., 2007). They were also added in the internal aqueous phase but microdroplets were formed because solid lyophilized proteins were incorporated. This so-called s/w/o/w method exhibited nearly zero-order kinetics for lysozyme, gonadorelin, leuprolide acetate and rhGH. Recently, sucrose acetate isobutyrate (SAIB) was added in the organic phase to form a highly-viscous hydrogel in water. The high viscosity of this sucrose derivative enabled prolonged and complete lysozyme release for up to 2 months (Lee et al., 2006). Therefore, it minimized the burst release and continuously discharged the protein; it also reduced PLGA degradation protecting the protein from denaturing conditions. Similarly, glycol chitosan (GC), a chitosan derivative conjugated to ethylene glycol, was incorporated in PLGA microspheres to stabilize lysozyme (Lee et al., 2007). GC viscous properties allowed a continuous lysozyme release up to $78 \%$ for one month. As chitosan degradation is mainly induced by lysozyme hydrolysis activity, presence of lysozyme may be necessary for this strategy.

\subsubsection{Use of a more hydrophilic polymer}

Low release levels from PLGA microspheres are partly due to the hydrophobic nature of the polymer. Indeed, when a hydrophobic blocked (capped) polymer is employed, a slower release rate of rhIGF-I (Lam et al., 2000) and of a somatostatin analogue (Blanco-Prieto et al., 2004) has been observed in comparison to the use of the uncapped form. For that reason, the use of promising new polymers that are more hydrophilic than PLGA have emerged, 
especially with the commercialization of some copolymers of PLGA and PEG. These polymers are more compatible with proteins; especially since they reduce protein adsorption and favour homogeneous distribution within the matrix. Besides, they increase water uptake within the microspheres.

Several types of modified polymers have been synthesized. Copolymers consisting of PLA and PEG, polylactide-co-poly(ethylene glycol) (PELA) have been designed with limited success (Zhou et al., 2003). Although they presented lower burst release, higher release rates, and the earlier onset for the second burst release for human serum albumin and glucose oxidase (GOD) loaded in PELA-microspheres, no complete release was reported and a loss of specific activity was detected for the released GOD after 7 days (67\% of activity) (Li et al., 2000; Deng et al., 2001). Microspheres based on monomethoxypoly(oxyethylene)-poly(lactic acid) diblock copolymers (MPOE-PLA) did not avoid incomplete release either. Indeed, a plateau was reached after approximately 10 days of BSA release from these microspheres (Bouillot et al., 1999). Brush-like branched polyesters, obtained by grafting PLGA onto poly(vinyl alcohol) (PVA) backbones, were also investigated to allow modification of the release pattern over a broader range (Frauke Pistel et al., 2001). PVA-graft-PLGA (PVA-gPLGA), offers additional degrees of freedom to manipulate properties such as molecular weight, glass transition temperature and hydrophilicity for higher compatibility with proteins. Drug release rates from PVAL-g-PLGA microspheres were improved resulting in more continuous release profiles by contrast to PLGA microspheres. Nevertheless, no complete release was observed.

Block copolymers consisting of PLGA alternating with poly (ethylene oxide) (PEO) were also developed. These block copolymers showed striking differences in their physicochemical properties compared to their homopolymers. For instance, the water uptake of 
microspheres consisting of ABA-triblock copolymers (PLGA A-blocks and PEO B-blocks) was markedly enhanced compared to PLGA microspheres (Kissel et al., 2002). A combined mechanism of swelling and erosion led to a hydrogel-like structure within these devices. This structure allowed the continuous and molecular mass-dependant release of macromolecular drugs (different forms of dextran). This profile really differs from the one observed with PLGA devices which is biphasic and almost independent of the molecular mass of the drug (Kissel et al., 1996). Besides, the in vitro release pattern of several model proteins was comparable to that of the model molecule dextran $40 \mathrm{kDa}$ in the initial release phase. Microspheres loaded with erythropoietin (EPO) and prepared by a water-in-oil-in-water (w/o/w) emulsion encapsulation procedure exhibited a continuous in vitro release for up to 2 weeks (Morlock et al., 1998; Koll et al., 2002). However, EPO release levelled off at later time points. The formation of EPO aggregates at the later stages of the release was probably induced by the presence of PEO itself which is known to precipitate proteins. For tetanus toxoid, another protein prone to aggregation, similar stability issues were encountered (Jung et al., 2002). Therefore, further optimization of the ABA polymer composition may be necessary to fully exploit the potential of these new materials. In the same way, microparticles forming a hydrogel-like structure upon contact with water were prepared with a blend of PLGA and oligo-ethylene glycol grafted poly(l-lactide) (PLLA-g-oligoEG) (Cho et al., 2001). BSA was continuously and completely released via diffusion from this swollen matrix. Otherwise, a triblock copolymer PLGA-PEG-PLGA was prepared with a lower Mw (Mw 1,500-1,000-1,500) (Kwon et al., 2004). Its unusual, sol-gel transition property was used to prepare microspheres without using organic solvents. in vitro studies of insulin release exhibited a low initial burst and a sustained and nearly complete release over 3 weeks $(>85 \%)$ 


\subsection{Preventing the formation of the deleterious environment}

Rather than stabilizing the protein during release, some work has focused on avoiding the occurrence of protein destabilization mechanisms. These experiments were based on the reasoning that protein release profiles can be optimized if the release is not controlled by polymer erosion. The matrix polymer degradation and microsphere characteristics were modified to allow total protein release prior to polymer degradation.

\subsubsection{Delay of polymer degradation}

Polymer hydrolytic degradation depends on many factors such as the molecular weight, the copolymer composition and the crystallinity of the polymer, all of which control water accessibility to the ester linkage (Anderson et al., 1997; Batycky et al., 1997; Freiberg et al., 2004). A change of one of these parameters will induce a variation in the protein release profile as protein destabilization is related to a large extend to polymer degradation kinetics. Therefore, if polymer degradation is delayed, the protein will be released before it can interact with the degrading polymer.

The degradation of polymer microspheres shows a clear dependence on the polymer's molecular weight (inherent viscosity). Longer polymers require a longer time to degrade and hence induce a longer release time of low molecular weight drugs. For proteins, the release rate during the second phase of the release (erosion of the polymer) also depends to a large extent on the polymer's molecular weight. Contrary to classical observations made with low molecular weight drugs, protein release may be slower when the molecular weight of the PLGA decreases. Indeed, protein release from PLGA microspheres is not only governed by the PLGA erosion rate and protein diffusion through the water-filled channels, it is also highly affected by the protein properties and their possible interaction with PLGA and its 
degradation products. Boury et al. (Boury et al., 1997) investigated BSA release from $10 \mu \mathrm{m}$ microspheres prepared with 50:50 PLGA of two different molecular weights (15 and 87kD). A quasi-absence of burst effect was observed with the lowest Mw polymer but it was followed by an incomplete release after one month. With the higher Mw PLGA, a high initial release of BSA was recorded in the first hours and thereafter, the remainder of the encapsulated BSA was completely released over the following 15 days. The authors explained this by a higher affinity of BSA with the lower Mw polymer. During the degradation process, the appearance of ionized carboxylic groups was enhanced with the lowest molecular weight polymer. The interactions of these charged functional groups with the positively-charged groups of the protein probably led to its retention in the polymer matrix and consequently explained the slower release of the protein.

The copolymer composition also influences polymer degradation. It is clearly established that microspheres containing a higher percentage of glycolic acid (GA) units in the polymer backbone will degrade faster than those with lower percentage of GA units due to their high reactivity with water. The hydrolytic cleavage of ester bonds to alcohol and carboxylic acid autocatalyzes the degradation process and more L-lactic acid is generated in the medium. Therefore, the local acidity is increased in microspheres containing a higher GA mol ratio in the polymer and they might be more prone to incomplete release (Park et al., 1995).

Water uptake into the polymer is influenced by the ratio of crystalline to amorphous regions: in general, amorphous regions are more easily affected by hydrolysis (Park et al., 1995). In agreement with previous observations, Kim and Park (Kim et al., 2004) demonstrated that the use of semi-crystalline, relatively low molecular weight (10kD), and slow degrading poly(L-lactic acid) (PLA), better control the rhGH release profile from 
microspheres than the use of amorphous and fast-degrading PLGA. Semi-crystalline PLA microspheres have a nano-porous structure on the pore wall due to the preferential crystallization of PLA during the in-water solvent evaporation process; sustained release was observed (100\% in 34 days). As polymer degradation/erosion processes occurred after completing the protein release, the acidic microenvironment problem affecting protein instability events were avoided.

\subsubsection{Preparation of porous microspheres}

Processing conditions employed during the preparation of microspheres determine the properties of the microspheres, such as the size, morphology, encapsulation efficiency, and drug distribution. All these properties influence the release of the drug from the delivery system. Among these variables, the morphology of microspheres, especially their porosity, plays a key role in modulating drug release (Freiberg et al., 2004); a large number of pores may greatly increase the rate of drug expulsion (Yang et al., 2000). Porosity is determined during microsphere hardening as the organic solvent evaporates during preparation and is influenced by the preparation temperature, solvent removal rate, and the volume of internal water phase when the common solvent evaporation technique is employed.

To enable a better water uptake and an easier diffusion of the protein and of the polymer degradation products out of the polymer, porous microspheres were prepared by a range of groups. Biodegradable PLA or PLGA have been codissolved with various biocompatible hydrophilic or amphiphilic compounds in the encapsulation procedure to prevent acidic microclimate-induced instability reactions of proteins in degrading polymers. 
For instance, PLGA was blended with pore-forming PEG in order to enhance the release of EPO, FITC-IgG , ovalbumin and insulin (Cleek R. L. et al., 1997; Morlock et al., 1998; Lavelle et al., 1999; Yeh et al., 2000). But, a burst and a steady rate of protein release in vitro were observed over 1 month. Complete release was not reached due to the presence of protein aggregates. To reduce the $\mathrm{pH}$ drop, PLGA was replaced by the slowly degrading PLA. The use of PLA/PEG blend resulted in much reduced fragmentation and aggregation of the protein related to a stable microparticle morphology over 4 weeks (Lavelle et al., 1999; Yeh et al., 2000; Jiang et al., 2001). When the PEG content in the blend was less than 20\%, BSA release was incomplete and insoluble non-covalent BSA aggregates were observed in the residual device (Jiang et al., 2001). In contrast, when PEG content was between 20 and 30\%, continuous release was improved and BSA remained structurally intact.

In order to improve protein release from PLGA microspheres, protein-loaded microspheres consisting of blends of PLGA and non-ionic poly (ethylene oxide)-poly (propylene oxide) copolymers (poloxamers) were also prepared. Poloxamers are available in a wide range of molecular weights and hydrophilicity and thus provide further opportunities for varying the characteristics of protein release from microparticles. Linear protein release profiles over 25 days were exhibited by incorporating hydrophilic poloxamer 407 in PLGA microparticles obtained by water-in-oil-in-oil (w/o/o) encapsulation procedure (Yeh et al., 1996). In contrast to PEG blended with PLGA, poloxamer resists the washing and the encapsulation process because of physical entanglements and complex formation (due to hydrogen bonding) between PLGA and poloxamer chains (Park et al., 1992). Poloxamer is embedded in the hydrophobic matrix and its extraction is retarded. With more hydrophobic copolymers (poloxamer 401), the release profile had a propensity to plateau after 10 days. This was attributed to the absence of developed porosity in the microparticles. Poloxamer 188 was also used to prepare poloxamer/PLGA microparticles by solid-in-oil-in-oil (s/o/o) 
method. The lag phase was reduced and a more continuous release than with PLGA microparticles was observed. It is important to notice that the microsphere diameter was increased by the presence of the poloxamer in the s/o/o procedure (Carrasquillo et al., 2001).

Recently, an original approach based on a pore-closing process of preformed porous microspheres has been reported (Kim et al., 2006). A sustained release of rhGH over one month was achieved. Highly porous PLGA microspheres were fabricated using Poloxamer 407 as an extractable porogen. Afterward, the microspheres were loaded with rhGH by dipping and the pores were closed by a water miscible solvent that partially dissolves PLGA. The result was a continuous release via a diffusion-controlled mechanism through the waterfilled porous channels. A similar strategy indicated the use of porous PLGA microspheres (obtained with Poloxamer 407) for sustained release of bFGF (Chung et al., 2006). The release was controlled by using the binding affinities of heparin to the growth factor. Hence, heparin was immobilized onto the surface of porous PLGA microspheres via covalent conjugation and the release was dictated by the dissociation rate of the bFGF-heparin complex.

\subsubsection{Minimization of the protein-polymer surface area}

From the above discussion, it becomes clear that a rational modification of PLGA microspheres is required to achieve a controlled release of a stabilized protein. With this purpose in mind, some techniques have been used to minimize the protein-polymer surface area.

An interesting approach is to coat the outer surface of protein sub-micron particles with PLGA to control the release by a dissolution controlled mechanism (Kim et al., 2001). 
PLGA only plays the role of a diffusion barrier during incubation time and protein-polymer interactions are reduced. The so-called $\mathrm{A}($ aggregate $) / \mathrm{O} / \mathrm{W}$ method consists of the protein aggregating in a reversibly dissociable form and in its subsequent coating by PLGA. This technique presents the advantage over the conventional s/o/w formulation to be a one-step process as the protein aggregates are formed during the spontaneous mixing of a water miscible organic solvent (ethyl acetate) with an aqueous protein solution. By using this technique, the formation of irreversible aggregates during processing is circumvented and the sustained release of the native monomeric form is achieved.

The minimization of the protein-polymer surface area by the use of microcapsules instead of microspheres was supposed to alleviate interaction between proteins and polymers (Park et al., 2006). Consequently, the preparation of reservoir-type microcapsules by a solvent exchange method has been detailed. This technique involves the collision between droplets of aqueous and organic solutions generated by a coaxial ultrasonic atomizer, the spreading of the organic solution on the aqueous core, and the mutual mass transfer of the solvents. Interestingly, the microcapsules released unaltered lysozyme in a sustained manner without a significant burst effect. The release rate was governed by diffusion through the polymer membrane layer.

To conclude this section 2.2., strategies that modify the PLGA microparticles seem to be relevant to avoid protein interactions with degrading polymers. While amorphous PLGA copolymers were the most widely used polymers in protein delivery because of the variety of PLGA copolymers commercially available, it soon became clear that it shows certain disadvantages for protein delivery, e.g. the triphasic protein release kinetics, the bulk erosion mechanism of degradation (an accumulation of acidic PLGA chains in the centre of the 
formulation), and its hydrophobicity. Therefore, though using relatively fast-degrading PLGA copolymers such as 50:50 PLGA for synchronizing a polymer degradation rate with a protein release rate, many attempts have been made to delay hydrolysis of the PLGA ester bonds to avoid acid build-up. Whereas this strategy has not been sufficient to release the protein continuously, water soluble compounds have been associated in the matrix to enhance microsphere porosity, or even a pore-closing process has been used to create a porous matrix without inducing burst effect. Finally, methods where protein-polymer interactions are reduced via a diffusion-controlled release have exhibited beneficial effects for protein release.

\section{Conclusion}

The development of biodegradable microparticles for protein drug delivery has been hindered by various obstacles due to protein instability issues such as their incomplete release from PLGA devices. The understanding of this mechanism has required studying the in vitro protein release in appropriate conditions and limiting effects as well as evaluating the integrity of the protein remaining inside the microspheres. Knowing the influence of the release medium and of the method of sampling is critical to fairly compare different formulations and to identify the best stabilizing strategy to adopt.

Approaches ensuring better protein release profiles from PLGA microparticles have been reported. They were based on the modification of either the microparticle formulation (protein, polymer, possible additives) or the microencapsulation process (protein microenvironment, microparticle formation). These strategies may be classified in two types: those tending to shield the protein from degradation and adsorption during the release period, and those tending to avoid these deleterious phenomenon to break out. 
An optimal strategy should protect the protein during the different stages of release. Moreover, it should be simple and transposable to any protein (even the more fragile and for low-loaded microspheres). Finally, it should not induce burst effect.

Taking into account these considerations, some of the reported strategies are highly relevant, such as the one concerning the refolding of the protein in the release medium, the one using more hydrophilic polymers, and the one creating a viscous microenvironment around the protein. Obviously, the association of different strategies is conceivable. It seems that the delivery of therapeutic proteins over a prolonged period is within reach. 


\section{References}

Al-Azzam, W., Pastrana, E. and Griebenow, K., 2002. Co-lyophilization of bovine serum albumin (BSA) with poly(ethylene glycol) improves efficiency of BSA encapsulation and stability in polyester microspheres by a solid-in-oil-in-oil technique, Biotechnol Letters, 24, $1367-1374$.

Anderson, J.M. and Shive, M.S., 1997. Biodegradation and biocompatibility of PLA and PLGA microspheres, Adv Drug Deliv Rev, 28, 1, 5-24.

Aubert-Pouessel, A., Bibby, D.C., Venier-Julienne, M.C., Hindre, F. and Benoit, J.P., 2002. A novel in vitro delivery system for assessing the biological integrity of protein upon release from PLGA microspheres, Pharm Res, 19, 7, 1046-51.

Aubert-Pouessel, A., Venier-Julienne, M.C., Clavreul, A., Sergent, M., Jollivet, C., MonteroMenei, C.N., Garcion, E., Bibby, D.C., Menei, P. and Benoit, J.P., 2004. In vitro study of GDNF release from biodegradable PLGA microspheres, J Control Release, 95, 3, 463-75.

Batycky, R.P., Hanes, J., Langer, R. and Edwards, D.A., 1997. A theoretical model of erosion and macromolecular drug release from biodegrading microspheres, J Pharm Sci, 86, 12, 14641477.

Bilati, U., Allemann, E. and Doelker, E., 2005. Strategic approaches for overcoming peptide and protein instability within biodegradable nano- and microparticles, Eur J Pharm Biopharm, 59, 3, 375-88. 
Blanco, D. and Alonso, M.J., 1998. Protein encapsulation and release from poly(lactide-coglycolide) microspheres: effect of the protein and polymer properties and of the coencapsulation of surfactants, Eur J Pharm Biopharm, 45, 3, 285-94.

Blanco-Prieto, M.J., Campanero, M.A., Besseghir, K., Heimgatner, F. and Gander, B., 2004. Importance of single or blended polymer types for controlled in vitro release and plasma levels of a somatostatin analogue entrapped in PLA/PLGA microspheres, J Control Release, $96,3,437-48$.

Bodmer, D., Kissel, T. and Traechslin, E., 1992. Factors influencing the release of peptides and proteins from biodegradable parenteral depot systems, J Control Release, 21, 1-3, 129138.

Bouillot, P., Ubrich, N., Sommer, F., Duc, T., M.Loeffler, J.P. and Dellacherie, E., 1999. Protein encapsulation in biodegradable amphiphilic microspheres, Int J Pharm, 181, 2, 15972.

Boury, F., Marchais, H., Proust, J.E. and Benoit, J.P., 1997. Bovine serum albumin release from poly([alpha]-hydroxy acid) microspheres: effects of polymer molecular weight and surface properties, J Control Release, 45, 1, 75-86.

Burke, P., 2000. Controlled release protein therapeutics: effects of process and formulation on stability. In: Wise, D. L. (Ed.), Handbook of pharmaceutical controlled release technology, Marcel Dekker, New York, pp. 661-692. 
Capan, Y., Jiang, G., Giovagnoli, S., Na, K.H. and DeLuca, P.P., 2003. Preparation and characterization of poly(D,L-lactide-co-glycolide) microspheres for controlled release of human growth hormone, AAPS PharmSciTech, 4, 2, E28.

Carrasquillo, K.G., Stanley, A.M., Aponte-Carro, J.C., De Jesus, P., Costantino, H.R., Bosques, C.J. and Griebenow, K., 2001. Non-aqueous encapsulation of excipient-stabilized spray-freeze dried BSA into poly(lactide-co-glycolide) microspheres results in release of native protein, J Control Release, 76, 3, 199-208.

Castellanos, I.J., Al-Azzam, W. and Griebenow, K., 2005. Effect of the covalent modification with poly(ethylene glycol) on alpha-chymotrypsin stability upon encapsulation in poly(lacticco-glycolic) microspheres, J Pharm Sci, 94, 2, 327-40.

Castellanos, I.J., Cruz, G., Crespo, R. and Griebenow, K., 2002. Encapsulation-induced aggregation and loss in activity of gamma-chymotrypsin and their prevention, $\mathrm{J}$ Control Release, 81, 3, 307-19.

Cho, K.Y., Choi, S.H., Kim, C., Nam, Y.S., Park, T.G. and Park, J., 2001. Protein release microparticles based on the blend of poly(d,l-lactic-co-glycolic acid) and oligo-ethylene glycol grafted poly(l-lactide), J Control Release, 76, 275-284.

Chung, H.J., Kim, H.K., Yoon, J.J. and Park, T.G., 2006. Heparin immobilized porous PLGA microspheres for angiogenic growth factor delivery, Pharm Res, 23, 8, 1835-41. 
Cleek R. L., T.K.C., Eskin S.G., Mikos A.G., 1997. Microparticles of poly(DL-lactic-coglycolic acid)/poly(ethylene glycol) blends for controlled drug delivery, J Control Release, 48, 259-268.

Cleland, J.L., Duenas, E., Daugherty, A., Marian, M., Yang, J., Wilson, M., Celniker, A.C., Shahzamani, A., Quarmby, V., Chu, H., Mukku, V., Mac, A., Roussakis, M., Gillette, N., Boyd, B., Yeung, D., Brooks, D., Maa, Y.-F., Hsu, C. and Jones, A.J.S., 1997. Recombinant human growth hormone poly(lactic-co-glycolic acid) (PLGA) microspheres provide a long lasting effect, J Control Release, 49, 2-3, 193-205.

Costantino, H.R., Langer, R. and Klibanov, A.M., 1994. Moisture-induced aggregation of lyophilized insulin, Pharm Res, 11, 1, 21-9.

Costantino, H.R., Langer, R. and Klibanov, A.M., 1994. Solid-phase aggregation of proteins under pharmaceutically relevant conditions, J Pharm Sci, 83, 12, 1662-9.

Crotts, G. and Park, T.G., 1998. Protein delivery from poly(lactic-co-glycolic acid) biodegradable microspheres: release kinetics and stability issues, J Microencapsul, 15, 6, 699713.

Crotts, G. and Park, T.G., 1997. Stability and release of bovine serum albumin encapsulated within poly(,-lactide-co-glycolide) microparticles, J Control Release, 44, 2-3, 123-134. 
Crotts, G., Sah, H. and Park, T.G., 1997. Adsorption determines in-vitro protein release rate from biodegradable microspheres: Quantitative analysis of surface area during degradation, $\mathbf{J}$ Control Release, 47, 1, 101-111.

Deng, X., Zhou, S., Li, X., Zhao, J. and Yuan, M., 2001. In vitro degradation and release profiles for poly-dl-lactide-poly(ethylene glycol) microspheres containing human serum albumin, J Control Release, 71, 2, 165-73.

Diwan, M. and Park, T.G., 2001. Pegylation enhances protein stability during encapsulation in PLGA microspheres, J Control Release, 73, 2-3, 233-44.

Diwan, M. and Park, T.G., 2003. Stabilization of recombinant interferon-alpha by pegylation for encapsulation in PLGA microspheres, Int J Pharm, 252, 1-2, 111-22.

D'Souza, S.S. and DeLuca, P.P., 2006. Methods to assess in vitro drug release from injectable polymeric particulate systems, Pharm Res, 23, 3, 460-74.

Fournier, E., Passirani, C., Montero-Menei, C.N. and Benoit, J.P., 2003. Biocompatibility of implantable synthetic polymeric drug carriers: focus on brain biocompatibility, Biomaterials, 24, 19, 3311-31.

Frauke Pistel, K., Breitenbach, A., Zange-Volland, R. and Kissel, T., 2001. Brush-like branched biodegradable polyesters, part III. Protein release from microspheres of poly(vinyl alcohol)-graft-poly(D,L-lactic-co-glycolic acid), J Control Release, 73, 1, 7-20. 
Freiberg, S. and Zhu, X.X., 2004. Polymer microspheres for controlled drug release, Int J Pharm, 282, 1-2, 1-18.

Fu, K.Harrell, R., Zinski, K., Um, C., Jaklenec, A., Frazier, J., Lotan, N., Burke, P., Klibanov, A.M. and Langer, R., 2003. A potential approach for decreasing the burst effect of protein from PLGA microspheres, J Pharm Sci, 92, 8, 1582-91.

Harris, A.S. and Mitra, A.K., 1998. Peptide and protein pegylation II - clinical evaluation, Adv Drug Deliv Rev, 29, 1-2, 1.

Hora, M.S., Rana, R.K., Nunberg, J.H., Tice, T.R., Gilley, R.M. and Hudson, M.E., 1990. Release of human serum albumin from poly(lactide-co-glycolide) microspheres, Pharm Res, $7,11,1190-1194$.

Ibrahim, M.A., Ismail, A., Fetouh, M.I. and Gopferich, A., 2005. Stability of insulin during the erosion of poly(lactic acid) and poly(lactic-co-glycolic acid) microspheres, J Control Release, 106, 3, 241-52.

Jiang, G., Qiu, W. and DeLuca, P.P., 2003. Preparation and in vitro/in vivo evaluation of insulin-loaded poly(acryloyl-hydroxyethyl starch)-PLGA composite microspheres, Pharm Res, 20, 3, 452-9.

Jiang, G., Woo, B.H., Kang, F., Singh, J. and DeLuca, P.P., 2002. Assessment of protein release kinetics, stability and protein polymer interaction of lysozyme encapsulated poly(D,Llactide-co-glycolide) microspheres, J Control Release, 79, 1-3, 137-45. 
Jiang, W. and Schwendeman, S.P., 2001. Stabilization and controlled release of bovine serum albumin encapsulated in poly(D, L-lactide) and poly(ethylene glycol) microsphere blends, Pharm Res, 18, 6, 878-85.

Johansen, P., Men, Y., Audran, R., Corradin, G., Merkle, H.P. and Gander, B., 1998. Improving stability and release kinetics of microencapsulated tetanus toxoid by coencapsulation of additives, Pharm Res, 15, 7, 1103-10.

Johnson, O.L., Jaworowicz, W., Cleland, J.L., Bailey, L., Charnis, M., Duenas, E., Wu, C., Shepard, D., Magil, S., Last, T., Jones, A.J. and Putney, S.D., 1997. The stabilization and encapsulation of human growth hormone into biodegradable microspheres, Pharm Res, 14, 6, $730-5$.

Jung, T., Koneberg, R., Hungerer, K.D. and Kissel, T., 2002. Tetanus toxoid microspheres consisting of biodegradable poly(lactide-co-glycolide)- and ABA-triblock-copolymers: immune response in mice, Int $\mathrm{J}$ Pharm, 234, 1-2, 75-90.

Kim, H.K., Chung, H.J. and Park, T.G., 2006. Biodegradable polymeric microspheres with "open/closed" pores for sustained release of human growth hormone, J Control Release, 112, $2,167-174$.

Kim, H.K. and Park, T.G., 2004. Comparative study on sustained release of human growth hormone from semi-crystalline poly(L-lactic acid) and amorphous poly(D,L-lactic-co-glycolic acid) microspheres: morphological effect on protein release, J Control Release, 98, 1, 115-25. 
Kim, H.K. and Park, T.G., 2001. Microencapsulation of dissociable human growth hormone aggregates within poly(D,L-lactic-co-glycolic acid) microparticles for sustained release, Int $\mathbf{J}$ Pharm, 229, 1-2, 107-16.

Kim, H.K. and Park, T.G., 1999. Microencapsulation of human growth hormone within biodegradable polyester microspheres: protein aggregation stability and incomplete release mechanism, Biotechnol Bioeng, 65, 6, 659-67.

Kim, J.H., Taluja, A., Knutson, K. and Han Bae, Y., 2005. Stability of bovine serum albumin complexed with PEG-poly(l-histidine) diblock copolymer in PLGA microspheres, J Control Release, 109, 1-3, 86-100.

Kissel, T.Li, Y. and Unger, F., 2002. ABA-triblock copolymers from biodegradable polyester A-blocks and hydrophilic poly(ethylene oxide) B-blocks as a candidate for in situ forming hydrogel delivery systems for proteins, Adv Drug Deliv Rev, 54, 1, 99-134.

Kissel, T.Li, Y.X.Volland, C.Gopferich, S. and Koneberg, R., 1996. Parenteral protein delivery systems using biodegradable polyesters of ABA block structure, containing hydrophobic poly(lactide-co-glycolide) A blocks and hydrophilic poly(ethylene oxide) B blocks, J Control Release, 39, 2-3, 315-326.

Koll, H., Winter, G., Kissel, T. and Morlock, M. Polypeptide-containing pharmaceutical forms of administration in the form of microparticles and method for the preparation thereof, 6,346,274, U.S., 2002. 
Kwon, Y.M. and Kim, S.W., 2004. Biodegradable triblock copolymer microspheres based on thermosensitive sol-gel transition, Pharm Res, 21, 2, 339-43.

Lagarce, F., Garcion, E., Faisant, N., Thomas, O., Kanaujia, P., Menei, P. and Benoit, J.P., 2006. Development and characterization of interleukin-18-loaded biodegradable microspheres, Int J Pharm, 314, 2, 179-88.

Lam, X.M., Duenas, E.T. and Cleland, J.L., 2001. Encapsulation and stabilization of nerve growth factor into poly(lactic-co-glycolic) acid microspheres, J Pharm Sci, 90, 9, 1356-65.

Lam, X.M., Duenas, E.T., Daugherty, A.L., Levin, N. and Cleland, J.L., 2000. Sustained release of recombinant human insulin-like growth factor-I for treatment of diabetes, J Control Release, 67, 2-3, 281-92.

Lavelle, E.C., Yeh, M.K., Coombes, A.G. and Davis, S.S., 1999. The stability and immunogenicity of a protein antigen encapsulated in biodegradable microparticles based on blends of lactide polymers and polyethylene glycol, Vaccine, 17, 6, 512-29.

Lee, E.S., Kwon, M.J., Lee, H. and Kim, J.J., 2007. Stabilization of protein encapsulated in poly(lactide-co-glycolide) microspheres by novel viscous S/W/O/W method, Int J Pharm, $331,1,27-37$.

Lee, E.S., Park, K., Park, I.S. and Na, K., 2007. Glycol chitosan as stabilizer for protein encapsulated into poly(lactide-co-glycolide) microparticles, Int J Pharm, 338, 310-316. 
Lee, E.S., Kwon, M.J., Lee, H., Na, K. and Kim, J.J., 2006. In vitro study of lysozyme in poly(lactide-co-glycolide) microspheres with sucrose acetate isobutyrate, Eur J Pharm Sci, 29, $5,435-441$.

Li, J.K., Wang, N. and Wu, X.S., 1997. A novel biodegradable system based on gelatin nanoparticles and poly(lactic-co-glycolic acid) microspheres for protein and peptide drug delivery, J Pharm Sci, 86, 8, 891-5.

Li, X., Zhang, Y., Yan, R., Jia, W., Yuan, M., Deng, X. and Huang, Z., 2000. Influence of process parameters on the protein stability encapsulated in poly--lactide-poly(ethylene glycol) microspheres, J Control Release, 68, 1, 41-52.

Lu, L., Yaszemski, M.J. and Mikos, A.G., 2001. TGF-beta1 release from biodegradable polymer microparticles: its effects on marrow stromal osteoblast function., Journal of Bone and Joint Surgery - Series A, 83 A Suppl 1, Pt 2,

Lucke, A., Fustella, E., Tessmar, J., Gazzaniga, A. and Gopferich, A., 2002. The effect of poly(ethylene glycol)-poly(D,L-lactic acid) diblock copolymers on peptide acylation, J Control Release, 80, 1-3, 157-68.

Makino, K., Ohshima, H. and Kondo, T., 1986. Mechanism of hydrolytic degradation of poly(L-lactide) microcapsules: effects of $\mathrm{pH}$, ionic strength and buffer concentration, $\mathrm{J}$ Microencapsul, 3, 3, 203-12. 
Mi, F.L., Shyu, S.S., Lin, Y.M., Wu, Y.B., Peng, C.K. and Tsai, Y.H., 2003. Chitin/PLGA blend microspheres as a biodegradable drug delivery system: a new delivery system for protein, Biomaterials, 24, 27, 5023-36.

Morita, T., Horikiri, Y., Suzuki, T. and Yoshino, H., 2001. Applicability of various amphiphilic polymers to the modification of protein release kinetics from biodegradable reservoir-type microspheres, Eur J Pharm Biopharm, 51, 1, 45-53.

Morita, T., Horikiri, Y., Yamahara, H., Suzuki, T. and Yoshino, H., 2000. Formation and isolation of spherical fine protein microparticles through lyophilization of proteinpoly(ethylene glycol) aqueous mixture, Pharm Res, 17, 11, 1367-73.

Morita, T., Sakamura, Y., Horikiri, Y., Suzuki, T. and Yoshino, H., 2001. Evaluation of in vivo release characteristics of protein-loaded biodegradable microspheres in rats and severe combined immunodeficiency disease mice, J Control Release, 73, 2-3, 213-21.

Morita, T., Sakamura, Y., Horikiri, Y., Suzuki, T. and Yoshino, H., 2000. Protein encapsulation into biodegradable microspheres by a novel S/O/W emulsion method using poly(ethylene glycol) as a protein micronization adjuvant, J Control Release, 69, 3, 435-44.

Morlock, M., Kissel, T., Li, Y.X., Koll, H. and Winter, G., 1998. Erythropoietin loaded microspheres prepared from biodegradable LPLG-PEO-LPLG triblock copolymers: protein stabilization and in-vitro release properties, J Control Release, 56, 1-3, 105-15. 
Nam, Y.S., Song, S.H., Choi, J.Y. and Park, T.G., 2000. Lysozyme microencapsulation within biodegradable PLGA microspheres: urea effect on protein release and stability, Biotechnol Bioeng, 70, 3, 270-7.

Park, J.H., Ye, M., Yeo, Y., Lee, W.K., Paul, C. and Park, K., 2006. Reservoir-type microcapsules prepared by the solvent exchange method: effect of formulation parameters on microencapsulation of lysozyme, Mol Pharm, 3, 2, 135-43.

Park, T.G., 1995. Degradation of poly(lactic-co-glycolic acid) microspheres: effect of copolymer composition, Biomaterials, 16, 15, 1123-30.

Park, T.G., Cohen, S. and Langer, R., 1992. Poly(L-lactic acid)/pluronic blends: characterizatin of phase separation behaviour, degradation and morphology and use as protein-releasing matrices, Macromolecules, 25, 116-122.

Park, T.G., Lu, W. and Crotts, G., 1995. Importance of in vitro experimental conditions on protein release kinetics, stability and polymer degradation in protein encapsulated poly(D,Llactic acid-co-glycolic acid) microspheres, J Control Release, 33, 2, 211-222.

Park, T.G., Yong Lee, H. and Sung Nam, Y., 1998. A new preparation method for protein loaded poly(D, L-lactic-co-glycolic acid) microspheres and protein release mechanism study, J Control Release, 55, 2-3, 181-91. 
Pean, J.M., Boury, F., Venier-Julienne, M.C., Menei, P., Proust, J.E. and Benoit, J.P., 1999. Why does PEG 400 co-encapsulation improve NGF stability and release from PLGA biodegradable microspheres?, Pharm Res, 16, 8, 1294-9.

Perez, C., Castellanos, I.J., Costantino, H.R., Al-Azzam, W. and Griebenow, K., 2002. Recent trends in stabilizing protein structure upon encapsulation and release from bioerodible polymers, J Pharm Pharmacol, 54, 3, 301-13.

Perez, C., Montano, N., Gonzalez, K. and Griebenow, K., 2003. Stabilization of achymotrypsin at the $\mathrm{CH} 2 \mathrm{Cl} 2 /$ water intrface and upon water-in-oil-in-water encapsulation in PLGA microspheres, J Control Release, 89, 71-85.

Rosa, G.D., Iommelli, R., La Rotonda, M.I., Miro, A. and Quaglia, F., 2000. Influence of the co-encapsulation of different non-ionic surfactants on the properties of PLGA insulin-loaded microspheres, J Control Release, 69, 2, 283-295.

Sah, H., 1999. Stabilization of proteins against methylene chloride/water interface-induced denaturation and aggregation, J Control Release, 58, 2, 143-51.

Sanchez, A., Villamayor, B., Guo, Y., McIver, J. and Alonso, M.J., 1999. Formulation strategies for the stabilization of tetanus toxoid in poly(lactide-co-glycolide) microspheres, Int J Pharm, 185, 2, 255-66.

Sandor, M., Enscore, D., Weston, P. and Mathiowitz, E., 2001. Effect of protein molecular weight on release from micron-sized PLGA microspheres, J Control Release, 76, 3, 297-311. 
Schwendeman, S.P., Cardamone, M., Klibanov, A., Langer, R. and Brandon, M.R. Stability of proteins and their delivery from biodegradable polymer microspheres. In Cohen, S. and Bernstein, H. (eds), Microparticulate systems for the delivery of proteins and vaccines (Cohen, S. and Bernstein, H., eds), Marcel Dekker, New York, 1996, pp. 1-49.

Shao, P.G. and Bailey, L.C., 1999. Stabilization of $\mathrm{pH}$-induced degradation of porcine insulin in biodegradable polyester microspheres, Pharm Dev Technol, 4, 4, 633-42.

Sinha, V.R. and Trehan, A., 2003. Biodegradable microspheres for protein delivery, J Control Release, 90, 3, 261-80.

Sturesson, C. and Carlfors, J., 2000. Incorporation of protein in PLG-microspheres with retention of bioactivity, J Control Release, 67, 2-3, 171-178.

Tamber, H., Johansen, P., Merkle, H.P. and Gander, B., 2005. Formulation aspects of biodegradable polymeric microspheres for antigen delivery, Adv Drug Deli Rev, 57, 3 SPEC. ISS., 357-376.

Van de Weert, M., Hennink, W.E. and Jiskoot, W., 2000. Protein instability in poly(lactic-coglycolic acid) microparticles, Pharm Res, 17, 10, 1159-67.

Visscher, G.E., Robison, R.L., Maulding, H.V., Fong, J.W., Pearson, J.E. and Argentieri, G.J., 1985. Biodegradation of and tissue reaction to 50:50 poly(DL-lactide-co-glycolide) microcapsules, J Biomed Mater Res, 19, 3, 349-65. 
Wang, J., Chua, K.M. and Wang, C.H., 2004. Stabilization and encapsulation of human immunoglobulin G into biodegradable microspheres, J Colloid Interface Sci, 271, 1, 92-101.

Wang, N., 1998. A novel approach to stabilization of protein drugs in poly(lactic-co-glycolic acid) microspheres using agarose hydrogel, Int J Pharm, 166, 1-14.

Wang, N., Wu, X.S. and Li, J.K., 1999. A heterogeneously structured composite based on poly(lactic-co-glycolic acid) microspheres and poly(vinyl alcohol) hydrogel nanoparticles for long-term protein drug delivery, Pharm Res, 16, 9, 1430-5.

Wang, W., 1999. Instability, stabilization, and formulation of liquid protein pharmaceuticals, Int J Pharm, 185, 2, 129-88.

Wang, W., 2005. Protein aggregation and its inhibition in biopharmaceutics, Int J Pharm, 289, $1-2,1-30$.

Woo, B.H., Jiang, G., Jo, Y.W. and DeLuca, P.P., 2001. Preparation and characterization of a composite PLGA and poly(acryloyl hydroxyethyl starch) microsphere system for protein delivery, Pharm Res, 18, 11, 1600-6.

Yang, J. and Cleland, J.L., 1997. Factors affecting the in vitro release of recombinant human interferon-gamma (rhIFN-gamma) from PLGA microspheres, J Pharm Sci, 86, 8, 908-14. 
Yang, Y.-Y., Chung, T.-S., Bai, X.-L. and Chan, W.-K., 2000. Effect of preparation conditions on morphology and release profiles of biodegradable polymeric microspheres containing protein fabricated by double-emulsion method, Chemical Engineering Science, 55, $12,2223-2236$.

Yeh, M.K., 2000. The stability of insulin in biodegradable microparticles based on blends of lactide polymers and polyethylene glycol, J Microencapsul, 17, 6, 743-56.

Yeh, M.K., Davis, S.S. and Coombes, A.G., 1996. Improving protein delivery from microparticles using blends of poly(DL lactide co-glycolide) and poly(ethylene oxide)poly(propylene oxide) copolymers, Pharm Res, 13, 11, 1693-8.

Zale, S.E., Burke, P.A., Bernstein, H. and Brickner, A. Composition for sustained release of non-aggregated erythropoietin, 5,716,644, US, 1997.

Zhou, S., Liao, X., Li, X., Deng, X. and Li, H., 2003. Poly-D,L-lactide-co-poly(ethylene glycol) microspheres as potential vaccine delivery systems, J Control Release, 86, 2-3, 195205.

Zhu, G., Mallery, S.R. and Schwendeman, S.P., 2000. Stabilization of proteins encapsulated in injectable poly (lactide- co-glycolide), Nat Biotechnol, 18, 1, 52-7.

Zhu, G. and Schwendeman, S.P., 2000. Stabilization of proteins encapsulated in cylindrical poly(lactide-co-glycolide) implants: mechanism of stabilization by basic additives, Pharm Res, 17, 3, 351-7. 


\section{Figures and tables}

\section{Figure legends}

Figure 1. In vitro lysozyme release in $\mathrm{pH} 2.5$ glycine buffer and in vivo release; the latter was plotted as cumulative area under serum level normalized as percent of the total area. Reprinted from (Jiang et al., 2002), with permission from Elsevier.

Figure 2. Critical steps in the sampling of the protein released from PLGA microspheres and possible solutions to avoid artefacts at each step.

Figure 3. Schematic illustration of protein release profile and mechanism of incomplete release from PLGA microspheres. Time scale is approximate and relative to 50:50 uncapped PLGA.

Figure 4. Schematic illustration of some strategies stabilizing the protein during the release period.

Figure 5. In vitro release of IL-18 from microparticles prepared by a w/o/w method (squares) and from microparticles prepared by a s/o/w method after protein colyophilisation with PEG (triangles). Reprinted from (Lagarce et al., 2006), with permission from Elsevier. 


\section{Figures}

Figure 1. In vitro lysozyme release in $\mathrm{pH} 2.5$ glycine buffer and in vivo release; the latter was plotted as cumulative area under serum level normalized as percent of the total area. Reprinted from (Jiang et al., 2002), with permission from Elsevier.

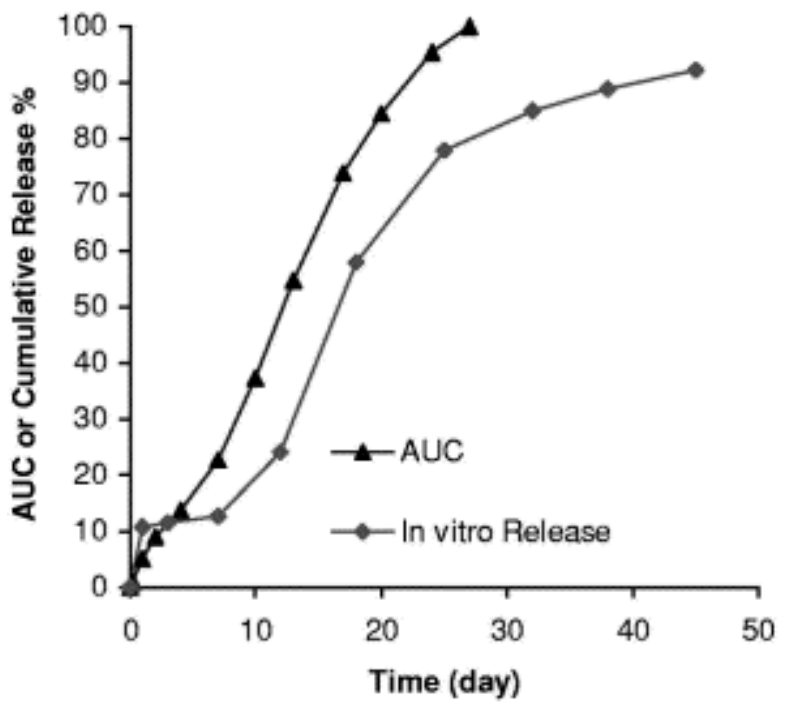


Sampling step

Possible artefacts

Solutions

Efficient buffer replacem ent (Park et al., 1995; Aubert-Pouessel et al., 2002)

Increased release volume (Kim et al., 2004)
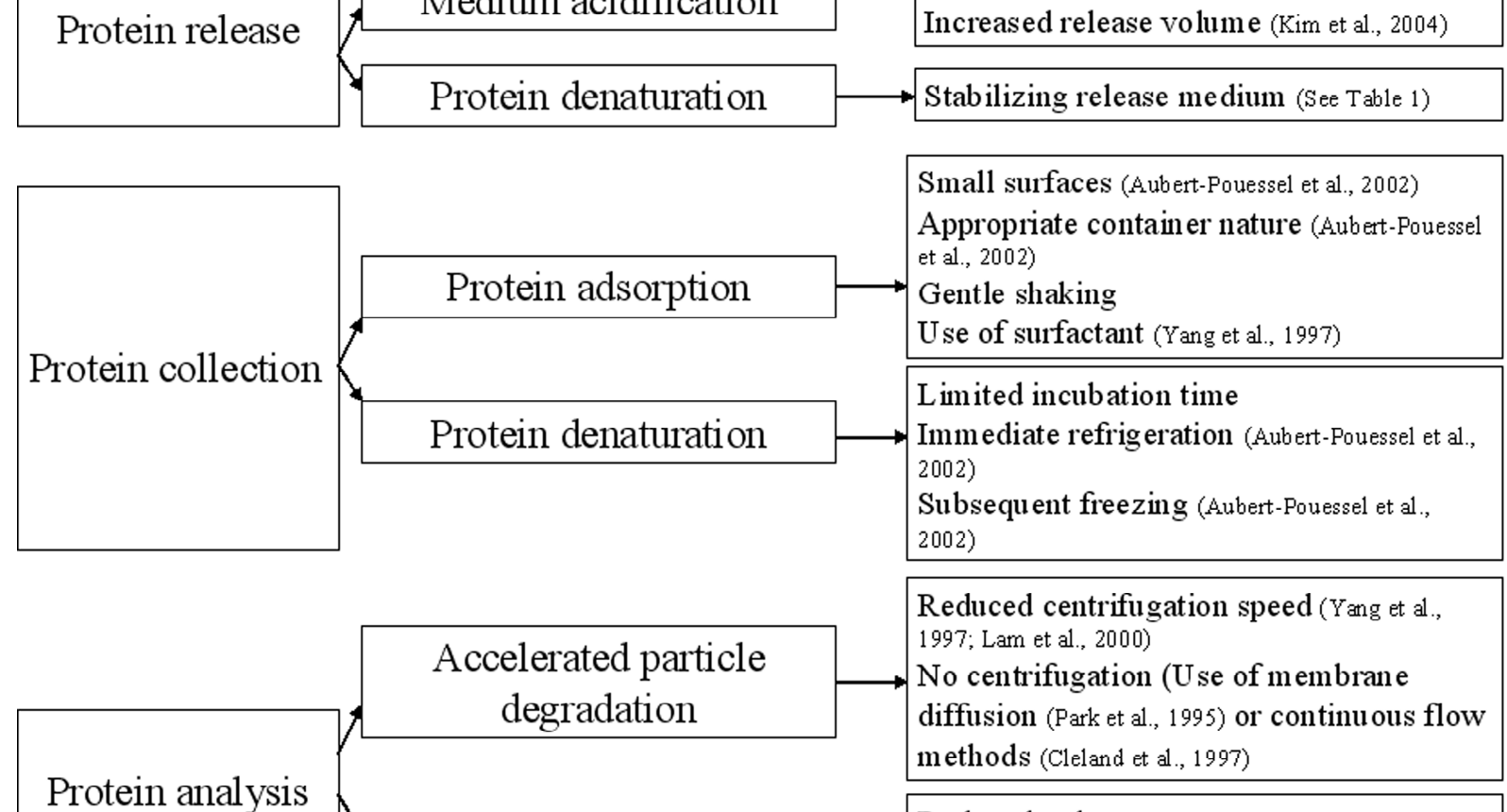

Low protein detection

Reduced volumes

Sen sitive analytical technique (Aubert-

Pouessel et al., 2004)

Figure 2. Critical steps in the sampling of the protein released from PLGA microspheres and possible solutions to avoid artefacts at each step. 


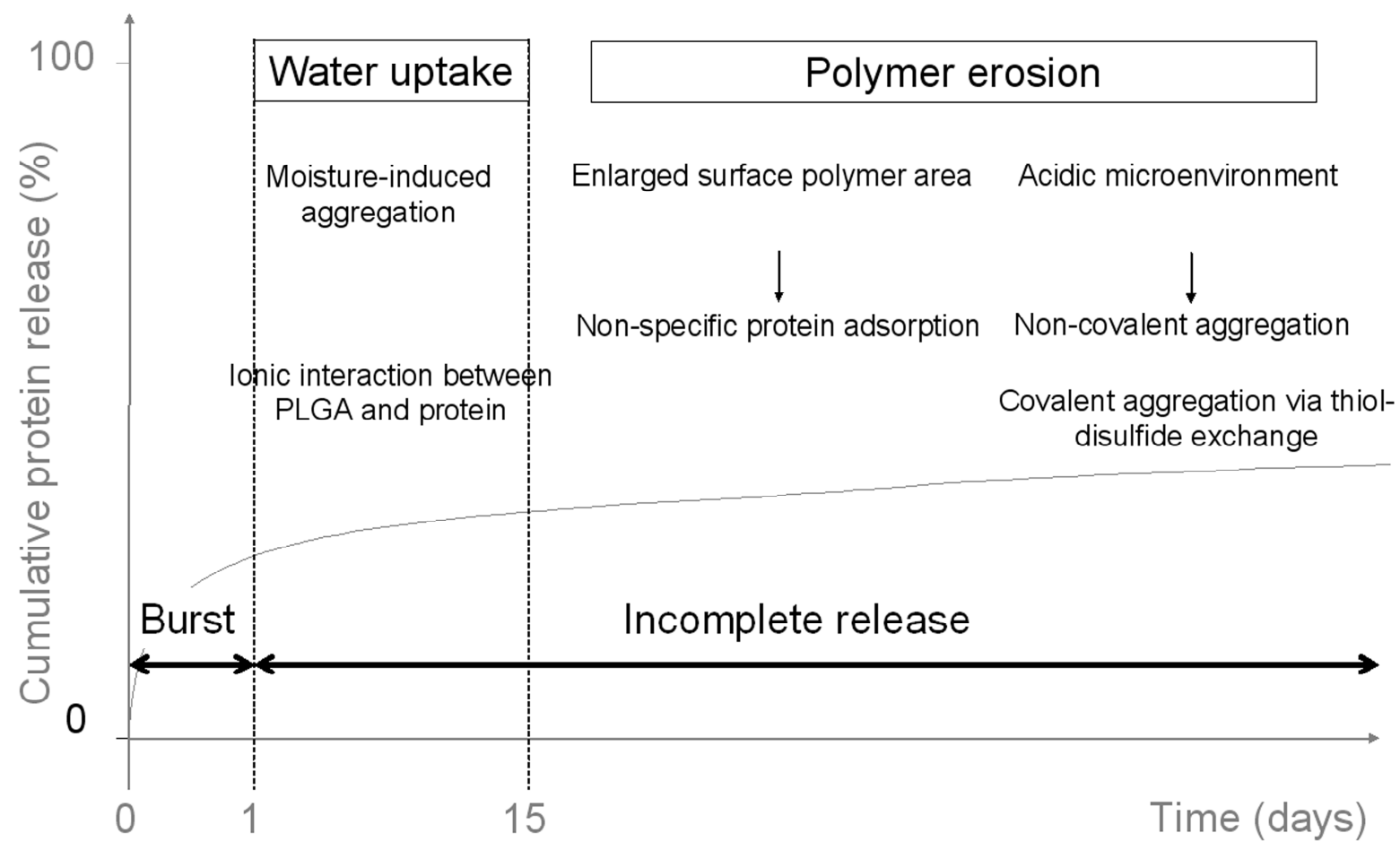

Figure 3. Schematic illustration of protein release profile and mechanism of incomplete release from PLGA microspheres. Time scale is approximate and relative to 50:50 uncapped PLGA. 


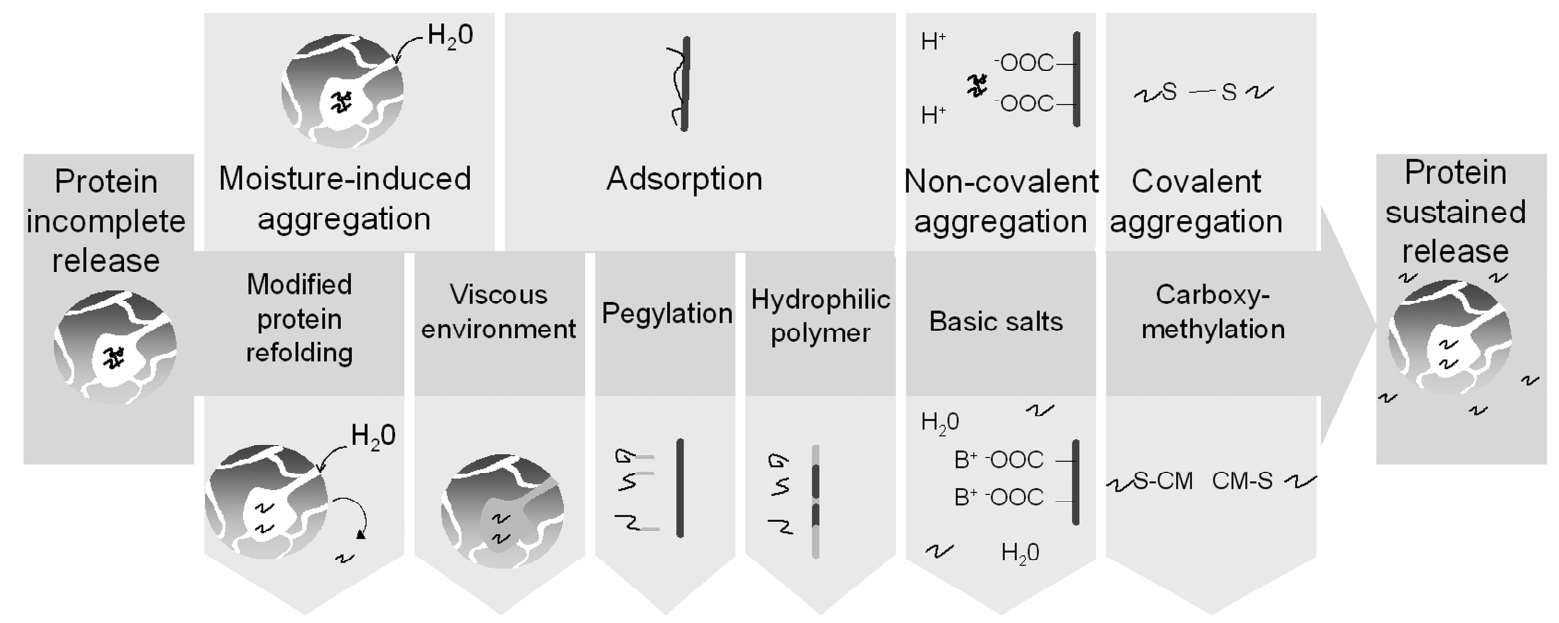

Figure 4. Schematic illustration of some strategies stabilizing the protein during the release period. 
Figure 5. In vitro release of IL-18 from microparticles prepared by a w/o/w method (squares) and from microparticles prepared by a s/o/w method after protein colyophilisation with PEG (triangles). Reprinted from (Lagarce et al., 2002), with permission from Elsevier.

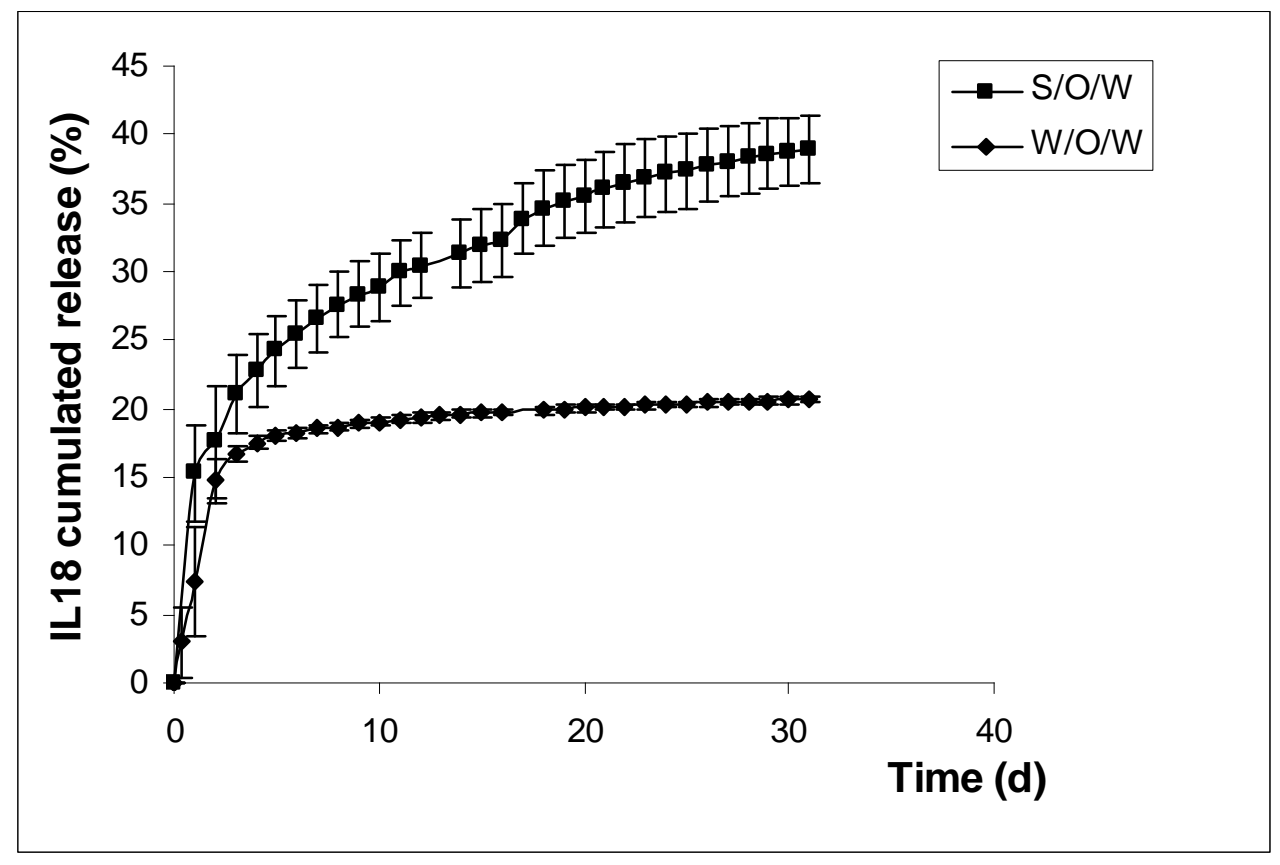




\section{Tables}

Table 1. Protein release studies from PLGA microspheres performed in "stabilizing" release medium at $37^{\circ} \mathrm{C}$.

\begin{tabular}{|c|c|c|}
\hline Protein formulation & Release medium & References \\
\hline$\alpha$-chymotrypsin & 10mM Phosphate buffer ( $\mathrm{pH} 5.0$ ) & (Castellanos et al., 2002) \\
\hline GDNF & $\begin{array}{c}10 \mathrm{mM} \text { Citrate buffer }(\mathrm{pH} 5.0) \\
+0.1 \% \text { BSA }\end{array}$ & (Aubert-Pouessel et al., 2004) \\
\hline r-met-HuGDNF & 10mM Citrate buffer (pH 5.0) & (Fu et al., 2003) \\
\hline IFN- $\gamma$ & $\begin{array}{l}5 \mathrm{mM} \text { Succinate buffer }(\mathrm{pH} 5.0) \\
\quad+0.01 \% \text { polysorbate } 20\end{array}$ & (Yang et al., 1997) \\
\hline IGF-1 & $\begin{array}{c}50 \mathrm{mM} \text { Acetate buffer }(\mathrm{pH} 5.4) \\
+0.02 \% \text { polysorbate } 20+100 \mathrm{mM} \mathrm{NaCl} \\
\end{array}$ & (Lam et al., 2000) \\
\hline \multirow{2}{*}{ Insulin } & $\begin{array}{l}50 \mathrm{mM} \text { TRIS-HCl buffer }(\mathrm{pH} 7.4) \\
\quad+0.02 \% \text { polysorbate } 80\end{array}$ & (Rosa et al., 2000) \\
\hline & 10mM Glycine buffer (pH 2.8) & (Jiang et al., 2003) \\
\hline \multirow{2}{*}{ Lysozyme } & $\begin{array}{l}\text { 100mM Acetate buffer ( } \mathrm{pH} 4.0) \\
\text { 100mM Glycine-HCl buffer (pH 2.5) }\end{array}$ & (Jiang et al., 2002) \\
\hline & $\begin{array}{l}\text { 84mM TRIS-HCl buffer (pH 7.4) } \\
\quad+0.09 \% \mathrm{NaCl}+0.1 \% \text { BSA }\end{array}$ & (Aubert-Pouessel et al., 2002) \\
\hline Tetanus toxoid & PBS (pH 7.2) & (Jung et al., 2002) \\
\hline
\end{tabular}


Table 2. Strategies commonly used to improve protein release from PLGA microspheres

\begin{tabular}{|c|c|c|}
\hline Srategy & Examples & References \\
\hline \multicolumn{3}{|l|}{ Protein stabilization } \\
\hline \multirow[t]{2}{*}{$\begin{array}{l}\text { Protein chemical } \\
\text { modification }\end{array}$} & Pegylation & $\begin{array}{l}\text { (Diwan et al., 2001; Diwan et al., } \\
\text { 2003: Castellanos et al. 2005) }\end{array}$ \\
\hline & Carboxy-methylated BSA & (Crotts et al., 1997) \\
\hline $\begin{array}{l}\text { Neutralization of PLGA } \\
\text { degradation products }\end{array}$ & Use of basic salts & $\begin{array}{l}\text { (Shao et al., 1999; Zhu et al., } \\
\text { 2000) }\end{array}$ \\
\hline \multirow[t]{4}{*}{ Help to protein refolding } & Unfolding with urea & (Nam et al., 2000) \\
\hline & Metal-induced precipitation & (Lam et al., 2001) \\
\hline & & (Zale et al., 1997) \\
\hline & Co-lyophilization with PEG & (Morita et al., 2000) \\
\hline \multirow[t]{3}{*}{$\begin{array}{l}\text { Formation of a viscous } \\
\text { microenvironment }\end{array}$} & $\begin{array}{l}\text { Starch, PVA, agarose inner } \\
\text { microparticles }\end{array}$ & $\begin{array}{l}\text { (Wang et al., 1998; Wang et al., } \\
\text { 1999; Woo et al., 2001; Capan et } \\
\text { al., 2003; Jiang et al., 2003) }\end{array}$ \\
\hline & Poloxamer 407 & (Sturesson et al., 2000) \\
\hline & $\begin{array}{l}\text { SAIB, starch, hyaluronate, } \\
\text { glycol chitosan }\end{array}$ & (Lee et al., 2006; Lee et al., 2007) \\
\hline \multirow[t]{2}{*}{$\begin{array}{l}\text { Use of a more hydrophilic } \\
\text { polymer }\end{array}$} & Uncapped polymer & $\begin{array}{l}\text { (Lam et al., 2000; Blanco-Prieto } \\
\text { et al., 2004) }\end{array}$ \\
\hline & Modified polymers & $\begin{array}{l}\text { (Cho et al, 2001; Frauke Pistel et } \\
\text { al., 2001; Kissel et al., 2002; } \\
\text { Zhou et al., 2003; Kwon et al., } \\
\text { 2004) }\end{array}$ \\
\hline \multicolumn{3}{|l|}{$\begin{array}{l}\text { Prevention of protein } \\
\text { destabilization } \\
\text { mechanisms }\end{array}$} \\
\hline \multirow{3}{*}{$\begin{array}{l}\text { Delay of polymer } \\
\text { degradation }\end{array}$} & High polymer Mw & (Boury et al., 1997) \\
\hline & $\begin{array}{l}\text { Low percentage of GA units } \\
\text { in the polymer }\end{array}$ & (Park et al., 1995) \\
\hline & More crystalline polymer & (Kim et al., 2004) \\
\hline \multirow[t]{3}{*}{$\begin{array}{l}\text { Preparation of porous } \\
\text { microspheres }\end{array}$} & $\begin{array}{l}\text { PLGA/PLA blends with } \\
\text { hydrophilic/ amphiphilic } \\
\text { molecules }\end{array}$ & $\begin{array}{l}\text { (Morlock et al., 1998; Lavelle et } \\
\text { al., 1999; Yeh et al., 2000; Jiang } \\
\text { et al., 2001; Mi et al., 2003) }\end{array}$ \\
\hline & Pore-closing process & (Kim et al., 2006) \\
\hline & $\begin{array}{l}\text { Heparin immobilized } \\
\text { microspheres }\end{array}$ & (Chung et al., 2006) \\
\hline \multirow[t]{2}{*}{$\begin{array}{l}\text { Minimization of protein- } \\
\text { polymer surface area }\end{array}$} & $\begin{array}{l}\text { Reservoir-type } \\
\text { microcapsules }\end{array}$ & (Park et al., 2006) \\
\hline & $\begin{array}{l}\text { Reversible aggregation with } \\
\text { organic solvent }\end{array}$ & (Kim et al., 2001) \\
\hline
\end{tabular}

